\title{
Correlates of weapon carrying among high school students in the United States
}

\author{
Adamson S Muula*1, Emmanuel Rudatsikira*2,3 and Seter Siziya ${ }^{4}$
}

Address: ${ }^{1}$ Department of Community Medicine and Public Health, University of Malawi, College of Medicine, Blantyre, Malawi, ${ }^{2}$ Department of Global Health, School of Public Health, Loma Linda University, California, USA, ${ }^{3}$ Department of Epidemiology and Biostatistics, School of Public Health, Loma Linda University, Loma Linda, California, USA and ${ }^{4}$ Department of Community Medicine, University of Zambia, School of Medicine, Lusaka, Zambia

Email: Adamson S Muula* - muula@email.unc.edu; Emmanuel Rudatsikira* - erudatsikira@llu.edu; Seter Siziya - ssiziya@yahoo.com

* Corresponding authors

Published: 7 July 2008

Annals of General Psychiatry 2008, 7:8 doi:10.1186/1744-859X-7-8

This article is available from: http://www.annals-general-psychiatry.com/content/7///8

(C) 2008 Muula et al; licensee BioMed Central Ltd.

This is an Open Access article distributed under the terms of the Creative Commons Attribution License (http://creativecommons.org/licenses/by/2.0), which permits unrestricted use, distribution, and reproduction in any medium, provided the original work is properly cited.
Received: II January 2008

Accepted: 7 July 2008

\begin{abstract}
Background: Deaths and injuries arising from interpersonal violence among adolescents are major public health concerns in the United States. The bearing of weapons among adolescents is a critical factor in many of these deaths and injuries.

Methods: A secondary analysis of the 2005 United States Youth Risk Behavior Surveillance System Survey data was carried out to examine the variables associated with self-reported history of weapon carrying on school property among high school students. We used logistic regression analysis to assess the associations.

Results: Of the 13,707 respondents who participated in the survey, $10.2 \%$ of males and $2.6 \%$ of females reported carrying a weapon on school property. In multivariate logistic regression analysis, males were more likely to report having carried a weapon than females (odds ratio $(O R)=5.58$; $95 \%$ confidence interval $(\mathrm{Cl})[4.23,7.62])$. Self-reported race/ethnicity was also associated with weapon carrying. Other variables positively associated with weapon carrying at school were substance use $(\mathrm{OR}=1.77 ; 95 \% \mathrm{Cl}[1.16,2.68])$, depression $(\mathrm{OR}=1.44 ; 95 \% \mathrm{Cl}[1.10,1.89])$, suicidal ideation $(\mathrm{OR}=1.64 ; 95 \% \mathrm{Cl}[1.23,2.19])$, having had property stolen or deliberately damaged at school $(\mathrm{OR}=1.55 ; 95 \% \mathrm{Cl}[\mathrm{I} .2 \mathrm{I}, \mathrm{I} .98])$, having been raped $(\mathrm{OR}=1.70 ; 95 \% \mathrm{Cl}[1.22$, $2.37])$, having been threatened or injured with a weapon on school property $(O R=2.19 ; 95 \% \mathrm{Cl}$ $[1.63,2.95])$, and having engaged in physical fighting $(\mathrm{OR}=2.02 ; 95 \% \mathrm{Cl}[1.56,2.63])$.
\end{abstract}

Conclusion: This research identifies factors that are associated with weapon bearing among adolescents in the United States. These factors may be important in the design of interventions aimed at improving school safety and adolescent health.

\section{Background}

There is growing interest in the study of interpersonal violence among adolescents [1-3]. The carrying of weapons on school property by adolescents is an important aspect of adolescent physical and mental health. Adolescents car- rying weapons on school property may cause physical injury and deaths among students and school staff [4]. Victims and witnesses of weapon use may also suffer psychological trauma from experiencing incidents where such weapons are displayed or used [5]. The learning envi- 
ronment within schools is disturbed if there is confirmed or suspected carrying of weapons by students.

In the recent past, there have been several high profile incidents in the United States that have highlighted the public health concern of weapon carrying among students. In 2004, the Centers for Disease Control and Prevention (CDC) estimated that $6.1 \%$ of high school students in the United States reported carrying weapons to school [6].

Previous research has reported that several factors are associated with carrying of weapons into schools. These factors include neighborhood and community factors, such as poverty and crime, family characteristics, school organization and climate. Individual level attributes such as gender, age and mental and psychological status of the person involved have also been reported to be associated with weapon bearing on school property [7-9].

In a study reported by Rudatsikira et al. [10] in which seventh to eighth grade students in school districts of the Southern California cities of Redlands and San Bernardino in the United States participated, $13.8 \%$ of the study participants reported having carried a weapon in the past 30 days. These authors also reported that previous victimization by the subject was associated with weapon carrying. A CDC report based on the 2005 Youth Risk Behavior Surveillance System (YRBSS) stated that "Overall, the prevalence of having carried a weapon was higher among male $(29.8 \%)$ than female $(7.1 \%)$ students" [11]. However, this CDC report did not assess whether being a victim of rape, having suffered deliberate property damage, having been threatened or injured and substance use were associated with carrying a weapon by the adolescent.

Based on the 2005 United States YRBSS, we carried out this study to report the prevalence of self-reported weapon carrying by in-school adolescents and to assess the association between weapon carrying and a selected list of explanatory variables such as race/ethnicity, sex, substance use, and previous victimization. The findings from this study may assist in the informed design of intervention programs aimed to reduce adolescent perpetrated injury and death resulting from weapon use.

\section{Methods}

\section{Sampling strategy in the Youth Risk Behavior Surveillance} System

This study was based on secondary analysis of data from the 2005 United States YRBSS. The YRBSS is an epidemiological surveillance system established by the CDC to monitor the prevalence of youth behaviors that most influence health [12]. The survey uses a three-stage cluster sample design to produce a representative sample of 9th through 12th grade students. In the 2005 survey, the target population consisted of all public, Catholic, and private school students in grades 9-12. Two hundred and three schools were sampled. In the first-stage, the sampling frame consisted of 1,261 primary sampling units (PSUs), consisting of counties, subareas of large counties, or groups of smaller, adjacent counties.

The 1,261 PSUs were categorized into 16 strata according to their metropolitan statistical area (MSA) status (that is, urbanicity) and the percentages of minority race/ethnicity groups (black and Hispanic students) in the PSUs. From the 1,261 PSUs, 57 were selected with probability proportional to overall school enrollment size for the PSU. In the second stage of sampling, 203 schools with any of grades 9-12 were selected with probability proportional to school enrollment size. The third stage of sampling consisted of randomly selecting, in each chosen school and in each of grades 9-12, one or two classrooms from either a required subject (for example, English or social studies) or a required period (for example, second period).

A weighting factor was applied to each student record to adjust for non-response and the oversampling of black and Hispanic students in the sample. The final, overall weights were scaled so that the weighted count of students was equal to the total sample size, and the weighted proportions of students in each grade matched population projections for each survey year.

In the 2005 survey, all regular public, Catholic, and other private school students in grades 9 through 12 in the 50 states and District of Columbia were included in the sampling frame. Puerto Rico, the trust territories, and the Virgin Islands were excluded from the sampling frame. Schools were selected systematically with probability proportional to enrollment in grades 9 through 12 using a random start.

All classes in a required subject or all classes meeting during a particular period of the day, depending on the school, were included in the sampling frame. Systematic equal probability sampling with a random start was used to select classes from each school that participated in the survey. Schools' response rate was $78 \%$ while students' response rate was $86 \%$. The overall response rate was $67 \%$.

\section{Questionnaire administration}

Survey procedures for the national, state, and local surveys were designed to protect students' privacy by allowing for anonymous and voluntary participation. Before survey administration, the CDC Institutional Review Board approved the study protocol and parental permission was obtained by participating schools. Students completed the 
self-administered questionnaire during one class period and recorded their responses directly on a computer-scannable booklet or answer sheet. The core questionnaire contained 87 questions. States and cities could add or delete questions from the core questionnaire. Skip patterns were not included in any YRBSS questionnaire to protect student privacy by ensuring all students took about the same amount of time to complete the survey.

\section{Measures}

A full presentation of the questions asked in the 2005 YRBSS has been reported by the CDC [12]. For the purpose of the current analysis, however, some of the questions of interest were as follow. With regards to weapon carrying, "During the past 30 days, on how many days did you carry a weapon such as a gun, knife, or club?" With regards to weapon carrying at school, "During the past 30 days, on how many days did you carry a weapon such as a gun, knife, or club on school property?" "During the past 12 months, how many times has someone threatened or injured you with a weapon such as a gun, knife, or club on school property?" "During the past 12 months, how many times has someone stolen or deliberately damaged your property such as your car, clothing, or books on school property?" "Have you ever been physically forced to have sexual intercourse when you did not want to?" A participant who reported "yes" to this last question was deemed to have been raped within the reported time period. The responses to these questions were dichotomized to yes or no; yes if the study participant reported experiencing an incident on at least one day and no if otherwise.

\section{Statistical analysis}

We obtained frequencies of key variables in order to describe the study sample. Logistic regression analysis was conducted to determine associations between weapon carrying on school property and a selected list of potential explanatory variables. These variables, identified from previous research on adolescent violence, included: substance use [13]; depression [14]; suicidal ideation [15]; physical fighting [16]; and prior victimization, such as having had property stolen or deliberately damaged at school, having been raped, and having been threatened or injured with a weapon on school property [17-23]. Bivariate logistic regression analyses were conducted between each of the explanatory variables and the outcome (weapon carrying). Further, multiple logistic regression analysis was conducted with each of the explanatory variables as the main exposure while the other variables were considered potential confounders. Data were analyzed and weighted using the SUDAAN statistical software [24]. SUDAAN Programming statements for Taylor Linearization $($ DESIGN $=$ WR $)$ allowed for accommodation of the complex survey design [25] so that the results are representative of students in grades 9-12 in public and private schools in the US.

\section{Results}

\section{Characteristics of the study participants}

Data for 13,707 students who participated in the study were analyzed; of these participants, 6,664 (50.5\%) were males and 7,193 (49.5\%) were females (Table 1). The median age was 16 years $(\mathrm{Q} 1=15$ years, $\mathrm{Q} 3=17$ years $)$.

Table I: Characteristics of adolescents in the 2005 Youth Risk Behavior Surveillance System (United States)

\begin{tabular}{|c|c|c|c|}
\hline Characteristic & $\begin{array}{l}\text { Total } \\
\%(n)\end{array}$ & $\begin{array}{l}\text { Males } \\
\%(n)\end{array}$ & $\begin{array}{c}\text { Females } \\
\%(n)\end{array}$ \\
\hline \multicolumn{4}{|l|}{ Age (years) } \\
\hline$<15$ & $10.7(I, 22 I)$ & $9.6(520)$ & 11.9 (70I) \\
\hline 15 & $26.4(3,170)$ & $25.6(1,450)$ & $27.6(1,720)$ \\
\hline 16 & $25.9(3,535)$ & $26.9(1,718)$ & $24.9(1,817)$ \\
\hline 17 & $23.3(3,661)$ & $23.0(1,780)$ & $23.7(1,881)$ \\
\hline $18+$ & $13.6(2,270)$ & $14.9(1,196)$ & $12.3(1,074)$ \\
\hline \multicolumn{4}{|l|}{ Ethnicity } \\
\hline White & $67.8(6,117)$ & $68.3(3,015)$ & $67.4(3,102)$ \\
\hline American Indian or Alaska native & $1.1(144)$ & $1.1(86)$ & $1.2(58)$ \\
\hline Asian & $3.7(366)$ & $4.0(187)$ & $3.4(179)$ \\
\hline Black & $16.0(3,343)$ & $15.6(1,575)$ & $16.5(1,768)$ \\
\hline Native Hawaiian or other Pacific Islander & $0.9(90)$ & $0.8(44)$ & $1.1(46)$ \\
\hline Hispanic & $10.5(2,063)$ & $10.3(920)$ & $10.6(1,143)$ \\
\hline Substance use (tobacco, alcohol, and illegal drugs) & $85.9(6,969)$ & $86.7(3,54 I)$ & $85.1(3,428)$ \\
\hline Depression & $28.5(4,136)$ & $20.4(1,477)$ & $36.7(2,719)$ \\
\hline Suicidal ideation & $16.9(2,330)$ & $12.0(772)$ & $21.8(1,558)$ \\
\hline Property stolen or deliberately damaged on school property & $29.7(4,132)$ & $31.4(2,105)$ & $28.0(2,027)$ \\
\hline Rape & $7.5(1,046)$ & $4.2(308)$ & $10.8(738)$ \\
\hline Threatened or injured with a weapon on school property & $7.9(1,083)$ & 9.7 (649) & $6.1(434)$ \\
\hline Physical fighting & $35.8(4,862)$ & $43.4(2,877)$ & $28.2(1,985)$ \\
\hline Weapon carrying on school property & $6.5(815)$ & $10.2(625)$ & $2.6(190)$ \\
\hline
\end{tabular}




\section{Prevalence of weapon carrying on school property}

Of the 13,707 participants, $10.2 \%$ of males and $2.6 \%$ of females reported carrying a weapon on school property. An estimated 29.8\% (95\% confidence interval (CI) [28.4, $31.2])$ of males and $19.3 \%$ (95\% CI [17.4, 21.3]) of females had carried weapons anywhere.

\section{Factors associated with carrying a weapon on school property: bivariate analysis}

Table 2 indicates that, according to bivariate analysis, there was no significant age difference in weapon carrying at school. Compared to female respondents, males were more than four times more likely to carry weapons to school (odds ratio $(\mathrm{OR})=4.22 ; 95 \%$ CI [3.40, 5.23])

Compared to whites, native Hawaiians or other Pacific
Islanders were more likely to carry weapons at school (OR $=2.82 ; 95 \%$ CI $[1.27,6.27])$. Other variables positively associated with carrying weapons at school were substance use $(\mathrm{OR}=2.35 ; 95 \%$ CI $[1.65,3.51])$, depression $(\mathrm{OR}=2.43 ; 95 \% \mathrm{CI}[1.94,3.03])$, suicidal ideation $(\mathrm{OR}=$ $2.75 ; 95 \%$ CI $[1.86,4.05])$, having property stolen or deliberately damaged by peers on school property $(\mathrm{OR}=$ $2.42 ; 95 \%$ CI $[2.02,2.90])$, physical fighting $(\mathrm{OR}=4.48$; $95 \%$ CI $[3.00,6.70])$, having been raped (OR $=3.51 ; 95 \%$ CI $[2.51,4.90])$, and having been threatened or injured with a weapon on school property $(\mathrm{OR}=5.43 ; 95 \% \mathrm{CI}$ $[4.38,6.74])$.

Table 2: Unadjusted associations between weapon carrying on school property and selected characteristics among US high school students, 2005

\begin{tabular}{|c|c|c|c|}
\hline \multirow[b]{2}{*}{ Characteristic } & \multicolumn{3}{|c|}{ OR $[95 \% \mathrm{Cl}]$} \\
\hline & Total & Males & Females \\
\hline \multicolumn{4}{|l|}{ Age (years) } \\
\hline$<15$ & 1.00 & 1.00 & 1.00 \\
\hline 15 & $1.19[0.83,1.89]$ & $1.08[0.69,1.68]$ & $1.14[0.54,2.37]$ \\
\hline 16 & $1.31[0.92,1.87]$ & $1.28[0.84,1.95]$ & $1.18[0.58,2.40]$ \\
\hline 17 & $1.19[0.83,1.71]$ & $1.20[0.78,1.85]$ & $1.07[0.52,2.20]$ \\
\hline $18+$ & $1.29[0.88,1.89]$ & $1.30[0.83,2.04]$ & $0.75[0.32,1.79]$ \\
\hline \multicolumn{4}{|l|}{ Gender } \\
\hline Female & 1.00 & & \\
\hline Male & $4.22[3.40,5.23]$ & & \\
\hline \multicolumn{4}{|l|}{ Ethnicity } \\
\hline White & 1.00 & 1.00 & 1.00 \\
\hline American Indian or Alaska native & $1.19[0.66,2.16]$ & $\mathrm{I} .47[0.78,2.78]$ & $0.06[0.01,0.45]$ \\
\hline Asian & $0.44[0.18,1.07]$ & $0.32[0.10,1.07]$ & $0.98[0.32,2.98]$ \\
\hline Black & $0.83[0.64,1.06]$ & $0.65[0.48,0.90]$ & $1.64[1.06,2.55]$ \\
\hline Native Hawaiian or other Pacific Islander & $2.82[1.27,6.27]$ & $4.43[1.77,11.07]$ & $1.65[0.22,12.26]$ \\
\hline Hispanic & $1.08[0.82,1.42]$ & $1.15[0.84,1.58]$ & $0.85[0.46,1.56]$ \\
\hline \multicolumn{4}{|l|}{ Substance use (tobacco, alcohol, and illegal drugs) } \\
\hline No & 1.00 & 1.00 & \\
\hline Yes & $2.35[1.65,3.5 \mathrm{I}]$ & $2.40[1.52,3.78]$ & $2.20[1.17,4.15]$ \\
\hline \multicolumn{4}{|l|}{ Depression } \\
\hline No & 1.00 & 1.00 & 1.00 \\
\hline Yes & $2.43[1.94,3.03]$ & $1.90[1.58,2.28]$ & $3.67[2.43,5.55]$ \\
\hline \multicolumn{4}{|l|}{ Suicidal ideation } \\
\hline No & 1.00 & 1.00 & 1.00 \\
\hline Yes & $2.75[1.86,4.05]$ & $3.33[2.60,4.25]$ & $2.29[1.88,2.79]$ \\
\hline \multicolumn{4}{|c|}{ Property stolen or deliberately damaged on school property } \\
\hline No & 1.00 & 1.00 & \\
\hline Yes & $2.42[2.02,2.90]$ & $2.25[1.82,2.77]$ & $2.78[1.90,4.06]$ \\
\hline \multicolumn{4}{|l|}{ Physical fighting } \\
\hline No & 1.00 & 1.00 & 1.00 \\
\hline Yes & $4.48[3.00,6.70]$ & $4.03[3.20,5.06]$ & $4.84[3.97,5.89]$ \\
\hline \multicolumn{4}{|l|}{ Rape } \\
\hline No & 1.00 & 1.00 & 1.00 \\
\hline Yes & $3.5 \mathrm{I}[2.5 \mathrm{I}, 4.90]$ & $4.05[3.09,5.32]$ & $2.60[2.13,3.17]$ \\
\hline \multicolumn{4}{|c|}{ Threatened or injured with a weapon on school property } \\
\hline No & 1.00 & 1.00 & 1.00 \\
\hline Yes & $5.43[4.38,6.74]$ & $4.83[3.75,6.22]$ & $5.79[3.68,9.12]$ \\
\hline
\end{tabular}




\section{Multivariate analysis of factors associated with carrying a} weapon on school property

Overall, the main findings from the multivariate analysis were unchanged for age, ethnicity, gender, substance use, depression, suicidal ideation, property stolen or deliberately damaged on school property, physical fighting, having been raped, and having been threatened or injured with a weapon on school property (Table 3 ).

\section{Discussion}

In a survey of US youth in 2005, 6.5\% reported carrying a weapon to school. More males $(10.2 \%)$ compared to females $(2.6 \%)$ carried a weapon in the 30 days preceding the survey. Another $7.9 \%$ reported having been threatened or injured with a weapon, $7.5 \%$ having been raped and $29.7 \%$ having ever had property deliberately damaged or stolen at school.
There were sex differences with regard to the prevalence and effect of depression, suicidal ideation, physical fighting, victimization rape and having been threatened or injured with a weapon on school property. Females were more than twice as likely $(10.8 \%)$ to report having been forced into sexual intercourse than males (4.2\%). More males, however, were more likely to have reported being threatened or injured with a weapon compared to females (9.7\% versus $6.1 \%$ ). Slightly more males than females ( $86.7 \%$ versus $85.1 \%$ ) were likely to have used substances (alcohol, tobacco or illicit drugs).

In bivariate logistic regression analysis, being male, native Hawaiian or Pacific Islander (whites as referent), substance use, depression, suicidal ideation, having been victimized (property stolen or deliberately damaged, raped or threatened or injured with a weapon), and physical

Table 3: Multivariate analysis of the associations between weapon carrying on school property and selected characteristics among US high school students, 2005

\begin{tabular}{|c|c|}
\hline Characteristic & OR $[95 \% \mathrm{Cl}]$ \\
\hline \multicolumn{2}{|l|}{ Age (years) } \\
\hline$<15$ & 1.00 \\
\hline 15 & $0.91[0.56,1.47]$ \\
\hline 16 & $1.21[0.76,1.94]$ \\
\hline 17 & $1.18[0.73,1.94]$ \\
\hline $18+$ & $1.21[0.73,2.03]$ \\
\hline \multicolumn{2}{|l|}{ Gender } \\
\hline Female & 1.00 \\
\hline Male & $5.68[4.23,7.62]$ \\
\hline \multicolumn{2}{|l|}{ Ethnicity } \\
\hline White & 1.00 \\
\hline American Indian or Alaska native & $0.82[0.42,1.60]$ \\
\hline Asian & $0.99[0.35,2.84]$ \\
\hline Black & $0.81[0.58,1.13]$ \\
\hline Native Hawaiian or other Pacific Islander & $4.67[1.66,13.14]$ \\
\hline Hispanic & $1.13[0.82,1.57]$ \\
\hline \multicolumn{2}{|c|}{ Substance use (tobacco, alcohol, and illegal drugs) } \\
\hline No & 1.00 \\
\hline Yes & $1.77[1.16,2.68]$ \\
\hline \multicolumn{2}{|l|}{ Depression } \\
\hline No & 1.00 \\
\hline Yes & $1.44[1.10,1.89]$ \\
\hline \multicolumn{2}{|l|}{ Suicidal ideation } \\
\hline No & 1.00 \\
\hline Yes & $1.64[1.23,2.19]$ \\
\hline \multicolumn{2}{|c|}{ Property stolen or deliberately damaged on school property } \\
\hline No & 1.00 \\
\hline Yes & $1.55[1.21,1.98]$ \\
\hline \multicolumn{2}{|l|}{ Rape } \\
\hline No & 1.00 \\
\hline Yes & $1.70[1.22,2.37]$ \\
\hline \multicolumn{2}{|c|}{ Threatened or injured with a weapon on school property } \\
\hline No & 1.00 \\
\hline Yes & $2.19[1.63,2.95]$ \\
\hline \multicolumn{2}{|l|}{ Fighting } \\
\hline No & 1.00 \\
\hline Yes & $2.02[1.56,2.63]$ \\
\hline
\end{tabular}


fighting were all associated with weapon carrying on school property. In multivariable analysis, the results regarding the association between any of the explanatory variables and weapon carrying at school remained virtually unchanged.

The present study confirms previous reports on the predictors of weapon carrying among adolescents [10,13-23]. In a study sample of 3,054 high school students in Massachusetts, DuRant et al. [17] found that physical fighting was positively associated with weapon carrying on school property. Simon et al. [14] conducted a study of 2,200 participants and reported that depression and drug use in the 9th grade were predictors of handgun carrying in 12th grade. Using data from more limited sample sizes, Rudatsikira et al. [10] and Sullivan et al. [20] reported a positive association between victimization and weapon carrying among adolescents. While some of the previous studies included much smaller sample sizes derived from specific local settings, our study benefited from a much larger national sample that could be perceived as representative of the US school-going adolescent population.

The sex differences where males were more likely to report carrying weapons to school than females possibly has multi-factorial influences. Bailey et al. [26] reported that the perception that other students are carrying guns may be a major factor in adolescent weapon bearing. It follows, therefore, that male students who bear weapons may only be doing so out of belief that their peers are also carrying weapons. Furthermore, numerous studies have reported that males may be more likely to be violent and engage in other unhealthy and antisocial behaviors, such as cigarette smoking, alcohol and other substance use, and physical fighting, than females [27-29]. This may reflect the acceptance and/or expectation of the 'macho' status that males are renowned for.

We have also demonstrated that study participants who had suffered forced sex or had been victimized in other ways were more likely to carry weapons compared to those who had not. Several studies have reported that perceptions of fear and safety concerns, having being threatened with a weapon and feelings of vulnerability are associated with weapon bearing, possibly with the motivation of self defense [30-33].

Native Hawaiian and other Pacific Islanders and Hispanics were more likely to have reported having carried a weapon on school grounds compared to whites. Blacks on the other hand were less likely to carry weapons on school grounds compared to whites. There was no difference between whites and Asians. What do these results mean?
Firstly, we need to state that we do not believe that there are any inherent genetic differences that determine race and that affect the way that adolescents behave. There has been what we consider a healthy debate as to whether racial/ethnic disparities in health are due to either innate genetic differences or the biological impact of present and past histories of racial discrimination and economic deprivation [34-39]. While this debate has sometimes been polarizing and emotional, there has not been enough evidence to substantiate the claim that race has genetic roots rather than being a social construct; however, even as a social construct, it has enormous potential to influence individual and societal behaviors and perceptions. We take the view, therefore, that racial categorization has facilitated the distribution of social and economic resources (housing, school districts, wealth, social networks) that may consequently influence adolescent behaviors and perceptions toward violent behavior [4043]. The perceptions that 'racial health disparities' are all genetic in origin and that race exists because of genetic differences have been discussed and possibly discarded by Krieger [44] and Kaufman and Cooper $[45,46]$. We take a similar view in interpreting the results of the current study.

We would have expected that minorities such as blacks (African Americans), being largely disadvantaged in the United States, would be more likely to bear weapons. This reasoning comes from the literature, where the poor are likely to live in violent neighborhoods and may be more likely to feel unsafe and therefore carry weapons to school. Our findings are therefore unexpected in as far as we had hypothesized that black adolescents will be at more risk of carrying weapons. There are possible explanations for these findings. Firstly, data were based on selfreport. It is possible that black adolescents would underreport their weapon carrying experiences. However, we do not have evidence to suggest that this is the case. Secondly, if the black adolescents who are more likely to be carrying weapons have dropped out of school, then it is possible that the weapon-carrying adolescents would be underrepresented. Thirdly, if black students felt less threatened at school, they may not thus carry weapons. Fourthly, black students may not carry weapons to school if the schools they attend are more vigilant in policing weapon carrying as a possible result of high violence and weapon bearing in black neighborhoods; if we knew this to be the case, it would suggest that such an intervention was effective. Finally, we may have been biased into thinking that blacks are more likely to carry weapons as a result of prevailing prejudices. However, we also do not intend to minimize the significantly higher risk of violent death by firearms among blacks compared to whites in the United States [47-50], although, with regard to our study, these data are limited by being largely from situations outside 
of school and among adults. These studies also report solely firearm injuries and deaths while our study includes all weapons, not just firearms. The higher likelihood of carrying a weapon among Hispanics may have similar associations with poverty or social factors.

Using students less than 15 years old as referents, we found that older students were more likely to report having carried weapons on school grounds. This could mean several things: that older adolescents may be at higher risk of perpetrating violence or being victimized; that older adolescents may be more likely to resort to violence to resolve conflicts [51]; or that peer influence or acceptance of weapon bearing is higher in this age group. Furthermore, older adolescents may be more likely to be successful in concealing weapons than much younger students.

The fact that adolescents who reported having suicidal ideation and depressive symptoms and substance use were also likely to bear weapons may be an example of 'clustering of harmful health behaviors' [27,52-56]; that is, an adolescent who uses substances is also likely to bear arms. As a policy direction, this calls for adolescent health intervention program policy makers and implementers to seriously consider that an adolescent who has one particular unhealthy behavior may also have other behaviors that need attention. A multi-problem and multifaceted approach has a better chance of promoting health than single vertical interventions.

\section{Limitation of the study}

Although the current analysis has strengths, there are also some limitations that need consideration. Firstly, the data used in the analysis were based on self-reports; therefore, bias could result from possible mis-reporting by participants, either intentionally or inadvertently. Furthermore, the response rate for this survey was $67 \%$ of all the eligible students. The experiences of the students who did not respond are not known. If, however, these non-responders had different experiences and exposures, our study may not be representative of the situation among US adolescents in schools. Finally, a small but not insignificant percentage of adolescents in the US are either home schooled, are truant or do not attend school altogether. Our findings may not be applicable to this group. It is also important to highlight the fact that data for this study were collected from a survey (cross-sectional methods) and so it is not possible to attribute causation to any of the factors so far identified as associated with weapon carrying [57-60].

\section{Conclusion}

This research identifies factors that may be used in the design of interventions aimed at improving school safety. Knowledge that males are more likely to carry weapons may enable the targeting of boys in prevention programs. Substance use prevention among adolescents may also be associated with reduced weapon carrying. We believe the racial/ethnic differences may be indicative of general socio-economic disparities existing across neighborhoods in the US. The mechanisms behind the disparities in weapon carrying with regard to socio-demographic characteristics also need to be explored.

\section{Competing interests}

The authors declare that they have no competing interests.

\section{Authors' contributions}

ASM participated in the interpretation of the results and drafting of the manuscript, ER conceived the analysis plan, conducted the statistical analyses and participated in the drafting of the manuscript, SS participated in the interpretation of the results and drafting of the manuscript. All authors approved the manuscript.

\section{Acknowledgements}

We are grateful to the Centers for Disease Control and Prevention (Atlanta, GA, USA) for providing us with the data from the Youth Risk Behavior Surveillance System.

\section{References}

I. Marsh L, McGee R, Nada-Raja S, Currey N: Adolescents' perceptions of violence and its prevention. Aust NZJ Public Health 2007, 3I:224-229.

2. Cunningham R, Walton M, Trowbridge M, Weber J, Outman R, Benway A, Maio R: Correlates of violent behavior among adolescents presenting to an urban emergency department. J Pediatr 2006, 149:770-776

3. Murakami S, Rappaport N, Penn JV: An overview of juveniles and school violence. Psychiatr Clin North Am 2006, 29:725-74I.

4. Mercy JA, Rosenberg ML: Preventing firearm violence in and around schools. In Violence in American Schools: A New Perspective Edited by: Elliot DS, Hamburg BA, Williams KR. New York: Cambridge University Press; 1998:159-187.

5. Kingery PM, Pruitt BE, Heuberger G: A profile of rural Texas adolescents who carry handguns to school. J Sch Health 1996, 66:18-24.

6. Centers for Disease Control and Prevention: Youth Risk Behavior Surveillance - United States, 2003 Washington, DC: US Department of Health and Human Services; 2004.

7. Afifi TO, Cox BJ, Katz LY: The associations between health risk behaviours and suicidal ideation and attempts in a nationally representative sample of young adolescents. Can J Psychiatry 2007, 52:666-674.

8. Khoury-Kassabri M, Benbenishty R, Astor RA: The effects of school climate, socioeconomic, and cultural factors on school victimization in Israel. Soc Work Res 2005, 29: 165-I80.

9. Khoury-Kassabri M, Benbenishty R, Zeira A, Astor RA: The contributions of community, family, and school variables to student victimization. Am J Community Psychol 2004, 34:187-204.

10. Rudatsikira E, Singh P, Job J, Knutsen S: Variables associated with weapon-carrying among young adolescents in Southern California. J Adolesc Health 2007, 40:470-473.

II. Eaton DK, Kann L, Kinchen S, Ross J, Hawkins J, Harris WA, Lowry R, McManus T, Chyen D, Shanklin S, Lim C, Grunbaum JA, Wechsler H: Youth Risk Behavior Surveillance - United States, 2005. MMWR 2006, 55: I - 108.

12. Centers for Disease Control and Prevention: 2005 Youth Risk Behavior Survey. [http://www.cdc.gov/yrbss]. Retrieved on December 6, 2007 
13. DuRant RH, Krowchuk DP, Kreiter S, Sinal SH, Woods CR Weapon carrying on school property among middle school students. Arch Pediatr Adolesc Med 1999, I 53(I):21-26.

14. Simon TR, Richardson JL, Dent CW, Chou CP, Flay BR: Prospective psychosocial, interpersonal, and behavioral predictors of handgun carrying among adolescents. Am J Public Health 1998, 88:960-963.

15. Swahn MH, Bossarte RM: Gender, early alcohol use, and suicide ideation and attempts: findings from the $\mathbf{2 0 0 5}$ youth risk behavior survey. J Adolesc Health 2007, 4 I: I75-I8I.

16. Lowry R, Powell KE, Kann L, Collins JL, Kolbe LJ: Weapon-carrying, physical fighting and fight-related injury among U.S. adolescents. Am J Prev Med 1998, I: I 22-129.

17. DuRant RH, Kahn J, Beckford PH, Woods ER: The association of weapon-carrying and fighting on school property and other health risk and problem behaviors among high school students. Arch Pediatr Adolesc Med 1997, I 5 I:360-366.

18. Leeb RT, Barker LE, Strine TW: The effect of childhood physical and sexual abuse on adolescent weapon carrying. J Adolesc Health 2007, 40:55I-558.

19. Malecki CK, Demaray MK: Carrying a weapon to school and perceptions of social support in an urban middle school. J Emot Behav Disord 2003, I I: 169-178.

20. Sullivan TN, Farrell AD, Kliewer W: Peer victimization in early adolescence: association between physical and relational victimization and drug use, aggression, and delinquent behaviors among urban middle school students. Dev Psycholpathol 2006, I 8(I): I19-137.

21. Crick NR, Bigbee MA, Howes C: Gender differences in children's normative beliefs about aggression: how do I hurt thee? Let me count the ways. Child Dev 1996, 67:1003-1014.

22. Prinstein MJ, Boergers J, Vernberg EM: Overt and relational aggression in adolescence: social-psychological adjustment in aggressors and victims. I Clin Child Psychol 200I, 30:479-49I.

23. Dowdell EB: The relationship between health risk behaviors and fear in one urban seventh grade class. J Pediatr Nurs 2003, 1 8: 187-194.

24. Shah BV, Barnwell BG, Bieler GS: SUDAAN User's Manual, Release 7.5 Research Triangle Park, NC: Research Triangle Institute; 1997.

25. Demnati A, Rao JNK: Linearization variance estimators for sur vey data. Statistics Canada 2004, 3:17-26 [http://www.statcan.ca/ english/ads/|2-00I-XIE/I2-00I-XIE200400I699I.pdf]. Retrieved 3 June, 2008

26. Bailey SL, Flewelling RL, Rosenbaum DP: Characteristics of students who bring weapons to school. I Adolesc Health 1997, 97(4): I-270.

27. Siziya S, Muula AS, Kazembe LN, Rudatsikira E: Harmful lifestyles' clustering among sexually active in-school adolescents in Zambia. BMC Pediatr 2008, 8:6.

28. Rudatsikira E, Dondog J, Siziya S, Muula AS: Prevalence and determinants of adolescent cigarette smoking in Mongolia. Singa pore Med J 2008, 49:57-62.

29. Kuzman M, Simetin IP, Franeliæ IP: Early sexual intercourse and risk factors in Croatian adolescents. Coll Antropol 2007, 3 I(Suppl 2): I 2 | - I 30 .

30. Simon TR, Dent CW, Sussman S: Vulnerability to victimization, concurrent problem behaviors, and peer influence as predictors of in-school weapon carrying among high school students. Violence Vict 1997, I 2:277-289.

31. Arria A, Borges G, Anthony JC: Fears and other suspected risk factors for carrying lethal weapons among urban youths of middle-school age. Arch Pediatr Adolesc Med 1997, I 5 I:555-560.

32. Arria A, Borges G, Anthony JC: Fears and other suspected risk factors for carrying lethal weapons among urban youths of middle-school age. Arch Pediatr Adolesc Med 1997, I 5 I:555-560.

33. McNabb SJ, Farley TA, Powell KE, Rolka HR, Horan JM: Correlates of gun-carrying among adolescents in south Louisiana. Am Prev Med 1996, I 2:96-102.

34. Duster T: Race and reification in science. Science 2005, 307: $1050-105 \mid$.

35. Hinds DA, Stuve LL, Nilsen GB, Halperin E, Eskin E, Ballinger DG Frazer KA, Cox DR: Whole-genome patterns of common DNA variation in three human populations. Science 2005, 307:1072-1079.

36. Holden C: Race and medicine. Science 2003, 302:594-596.
37. Bloche MG: Race-based therapeutics. N Engl I Med 2004, 35 I:2035-2037.

38. Cooper RS, Kaufman JS, Ward R: Race and genomics. N EnglJ Med 2003, 248: I I66-II70.

39. Kaplan JB, Bennett $\mathrm{T}$ : Use of race and ethnicity in biomedical publication. JAMA 2003, 289:2709-27/6.

40. Taylor TJ, Esbensen FA, Peterson D, Freng A: Putting youth violent victimization into context: sex, race/ethnicity, and community differences among a multisite sample of youths. Violence Vict 2007, 22:702-720.

4I. Melzer-Lange MD, Van Thatcher CD, Liu J, Zhu S: Urban community characteristics and adolescent assault victims. WM 2007, 106:394-396.

42. Molnar BE, Cerda M, Roberts AL, Buka SL: Effects of neighborhood resources on aggressive and delinquent behaviors among urban youths. Am J Public Health 2008, 98: I 086- 1093.

43. Masi CM, Hawkley LC, Piotrowski ZH, Pickett KE: Neighborhood economic disadvantage, violent crime, group density, and pregnancy outcomes in a diverse, urban population. Soc Sci Med 2007, 65:2440-2457.

44. Krieger N: Stormy weather: race, gene expression, and the science of health disparities. Am J Public Health 2005 , 95:2155-2160.

45. Kaufman JS, Cooper RS: Race in epidemiology: new tools, old problems. Ann Epidemiol 2008, I 8: II9-123.

46. Kaufman JS, Cooper RS: Commentary: considerations for use of racial/ethnic classification in etiologic research. Am J Epidemiol 200I, I 54:29I-298.

47. Lemaire ]: The effect of firearm deaths on life expectancy and insurance premiums in the United States. LDI Issue Brief 2005, I I: I-4.

48. Guileyardo JM, Carmody TJ, Lene WJ, Stone IC: Racial and ethnic patterns in firearms deaths. Am J Forensic Med Pathol 1994 I 5:328-330.

49. Centers for Disease Control and Prevention (CDC): Firearmrelated years of potential life lost before age 65 years United States, I980-1991. MMWR Morb Mortal Wkly Rep 1994, 43:609-6II

50. Centers for Disease Control and Prevention (CDC): Influence of homicide on racial disparity in life expectancy - United States, I 998. MMWR Morb Mortal Wkly Rep 200I, 0(36):780-783.

51. Blake CS, Hamrin V: Current approaches to the assessment and management of anger and aggression in youth: a review. J Child Adolesc Psychiatr Nurs 2007, 20:209-22I.

52. Holmberg LI, Hellberg D: Health, health-compromising behavior, risk-taking behavior and sexuality in female and male high school students in vocational compared with theoretical programs in Sweden. Int I Adolesc Med Health 2007, 19:459-472.

53. Kim YS, Koh YJ, Leventhal B: School bullying and suicidal risk in Korean middle school students. Pediatrics 2005, I I 5:357-363.

54. Saner H, Ellickson P: Concurrent risk factors for adolescent violence. J Adolesc Health 1996, 19:94-103.

55. Kshirsagar VY, Agarwal R, Bavdekar SB: Bullying in schools: prevalence and short-term impact. Indian Pediatr 2007, 44:25-28.

56. Park HS, Schepp KG, Jang EH, Koo HY: Predictors of suicidal ideation among high school students by gender in South Korea. J Sch Health 2006, 76:181-188.

57. Greenland S, Pearl J, Robins JM: Causal diagrams for epidemiologic research. Epidemiology 1999, 10:38-48.

58. Greenland S, Rothman KJ: Measures of effect and measures of association. In Modern Epidemiology 2nd edition. Edited by: Rothman KJ, Greenland S. Philadelphia, PA: Lippincott-Raven; 1998:48-66.

59. Kaufman JS, Cooper RS: Seeking causal explanations in socia epidemiology. Am J Epidemiol 1999, I 50: I | 3-1 20.

60. Rothman KJ: Causes. Am J Epidemiol 1976, 104:587-592 